\title{
Differences in Perception of Computer Sciences and Informatics due to Gender and Experience
}

\author{
Gabriela Marín \\ Universidad de Costa Rica, Escuela de Ciencias de la Computación e Informática, \\ San Pedro, Costa Rica, 1626-2050 \\ gmarin@ecci.ucr.ac.cr \\ E. Gabriela Barrantes \\ Universidad de Costa Rica, Escuela de Ciencias de la Computación e Informática, \\ San Pedro, Costa Rica, 2060 \\ gbarrantes@ecci.ucr.ac.cr \\ Silvia Chavarría \\ Universidad de Costa Rica, Posgrado en Computación e Informática, \\ San Pedro, Costa Rica, 1164-2350 \\ silviachava@yahoo.com
}

\begin{abstract}
Low participation of women in Computer Science (CS) has been documented in some countries. Since this phenomenon occurs in the Computer Science and Informatics Department at the Universidad de Costa Rica, we decided to investigate if there were gender differences in some factors, both motivating and inhibiting students to enter the field. Our main purpose was to see if those differences could help find factors influencing the imbalance of female participation. Both graduate and undergraduate populations were investigated. It was found that there were differences by gender in both populations. As a consequence of the knowledge of the field acquired during the permanence in the CS program and professional experience, both men and women change, although differently, their perceptions.
\end{abstract}

Keywords: Gender differences, Computer Science, participation, undergraduate program, graduate program, motivations, skills.

\section{Introduction}

The perception that there existed differences between female and male participation in the School of Computer Sciences and Informatics (ECCI) of the University of Costa Rica prompted a series of investigations in this area. In Marin (2007) [7] we presented some of the research results:

- We confirmed there is a difference in female and male participation at the undergraduate and postgraduate levels;

- We showed that the percentage of women admitted to the undergraduate program at our school is not only low, but has a shrinking tendency;

- We discovered that in the Masters program, the ratio of women being accepted is constant, and that women, proportionally to its population source, are seeking to enter the program in greater numbers;

- We found that women are more effective at graduating in both the undergraduate and graduate programs; 
- We confirmed that the low number of women graduating in the bachelor's and master's programs at our School is not the product of their inability to complete the studies, either because they were dropping off or deserting, but due to the low number of women entering the program.

In Marin (2007) [7], we raised a series of questions regarding the phenomenon of low women participation in Computing. The previous paragraph summarizes the answers to some of them. This article analyzes the issue further by studying the remaining questions. In this article, we deal with aspects of perception in which women and men could differ. The remaining questions are described below (those addressed directly in this article are shown in italics):

- What image do young men and women have of the Computer Sciences' study plan, and of the different types of job experiences they will encounter in this field? Will this image have an effect on their decision of which career they choose?

- Is there a difference or not in their perception regarding their own ability to continue in the Computer Sciences study plan?

- Do they, as gender groups, have the same opinion about their future employment at the undergraduate level and at the graduate level, since at this point the latter are already part of the labor market?

- Is there discrimination against women in the area of Computer Sciences, both during the studies and in professional environments? What effect does this discrimination might have in women's choice of career?

- Is there a gender difference in expected recruitment and employment benefits? Does this difference affect women's choice of career?

By Computing and Informatics (CI) we refer to any study plan and profession associated with the development and efficient use of computer equipment, and referred as Information Systems, Information Technology, Computer Sciences, etc. In this article we will focus on the Bachelor's program in CI taught at the School of Computer Sciences and Informatics (ECCI) from the Universidad de Costa Rica (UCR). The graduate program in Computing and Informatics at the UCR was established as a continuation of the Bachelor's program described above. The graduate population is relatively homogenous, with $80 \%$ of students coming from the undergraduate program in CI of our university, $15 \%$ coming from the undergraduate program in Computer Science of the Instituto Tecnológico de Costa Rica, a program very similar to ours, and the remaining 5\% coming from other Computer Science careers in other universities or from related careers (after following a strict "leveling program").

As noted in (Marin, 2007) [7], we state that the difference in participation by sex, not only in the area of computing, but also in other scientific and technical areas, is due to social factors rather than biological differences, i.e. they correspond to gender differences and not sexual differences. For the purpose of this article we define differences that are due to biology as sexual differences, while those issues caused by social, educational, economic, political, and employment factors, as gender differences.

In this research we want to determine if when considering populations divided by sex, gender differences make themselves apparent in factors that could affect decision taking 
regarding women entering or not in the computing field. Already in (Marin, 2007) [7] we had discussed the importance of increasing the proportion of women in the field.

\section{Factors that may be influencing women's participation}

This section will present the methodology, data and analysis of results of the first three questions in the survey used to study the possible gender differences in factors that might motivate or inhibit the participation of women in CI.

\subsection{Methodology}

To investigate factors that may be inhibiting women's participation in CI, two populations were surveyed: male and female students just entering the undergraduate program, and male and female active graduate students. Both populations are different, and have different knowledge of the subject. First year students are actually unaware of "what computing is", except for what they might have heard. Their perceptions represent the social notion of "what computing is." On the other hand, graduate students are already professionals in the field, or in similar disciplines, and know not only the curriculum but also are familiar with the field through its working environment.

The majority of first year students were surveyed during their initial enrollment process to obtain and compare perceptions of both populations. Of a total of 179 students admitted for 2007 (149 males and 30 females) 130 students (106 men and 24 women) were surveyed. As a result, $72.6 \%$ of the total population $(71.1 \%$ of total of men and $80 \%$ of all women) was polled on. In 2007 , the percentage of women admitted to the ECCI was only a $16.8 \%$, and $18.5 \%$ of the questionnaires were answered by them.

Similarly, during the process of graduate enrollment for the first semester of 2007, a survey was carried out for the same purposes. Of a total of 183 active students at the Masters' level (148 men and 35 women), 147 students (114 men and 33 women) completed the survey. In this case, $80.3 \%$ of the active population $(77 \%$ of men and $94.3 \%$ of all women) was polled. $22.4 \%$ of the students that answered the survey were women and $78.6 \%$ were men.

In this article we will only discuss the results of the first three questions in the survey. They relate to the possible motivational and inhibiting factors that might be affecting the choice to study CI.

The information will be presented and will be analyzed under three aspects: (1) on gender differences amongst undergraduate first year students - in the first column of each table, (2) on gender differences amongst graduate students - in the last columns of each table, and (3) the changes in perception amongst members of one sex, but between the two different populations - in the middle column of each table, called Change in Perceptions. For the two columns on Relative Difference, the most significant differences found in each cell will be highlighted, in green and yellow, because we believe they could reflect population trends. The cells of the table in these two columns that have not been highlighted are answers that are considered similar between sexes. Notice that positive values of relative difference indicate that the male population gave more importance to that particular aspect than the female population. For example, in 
Table 1, "I knew I would be good with computers" was selected by first year undergraduates as a cause to choose studying CI by a higher rate of men than women. Conversely, negative values of relative difference indicate that the female population gave more importance to the respective aspect. For easier understanding, the legends are "more $\delta^{\lambda}$ or "more $\bigcirc "$, respectively.

Finally, note that in the column Changes in Perception, " $>$ " represents men and " $\odot$ " women. A " $\downarrow "$ represents a decrease and a " $\uparrow "$ represents an increase, both of relative importance of the row category as a product of exposure to the computing curriculum and work experiences in the male and female populations. More drastic changes in

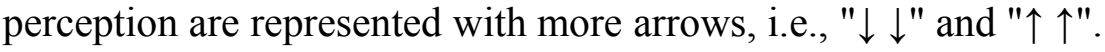

\subsection{Analysis of Results}

\subsection{1 "I chose to study CI because..."}

The results to the question: "I chose to study CI because... (More than one category can be selected)" are tabulated in Table 1. Note that although it is the same question for both groups, undergraduate and graduate students, for graduate students the decision to study computing was taken at least four years back, and their answers could be affected by their ability to remember, and in particular, can be biased by their experiences during their undergraduate studies and current work. For first year undergraduate students, the decision to study $\mathrm{CI}$ is newer and involves less personal knowledge of the discipline. We are interested in highlighting these differences, and we believe they should be investigated in depth.

Table 1. Reasons for choosing to study CI, for first year undergraduate students and active graduate students, by sex.

\begin{tabular}{|c|c|c|c|c|c|c|c|c|c|c|c|}
\hline \multirow{3}{*}{$\begin{array}{l}\text { Reasons for } \\
\text { chosing to study } \\
\text { computing }\end{array}$} & \multicolumn{5}{|c|}{ First year undergraduates } & \multirow{3}{*}{$\begin{array}{l}\text { Changes } \\
\text { in } \\
\text { perpection }\end{array}$} & \multicolumn{5}{|c|}{ Active graduate students } \\
\hline & \multicolumn{2}{|c|}{ Men } & \multicolumn{2}{|c|}{ Women } & \multirow{2}{*}{$\begin{array}{c}\text { Relative } \\
\text { difference }\end{array}$} & & \multicolumn{2}{|c|}{ Men } & \multicolumn{2}{|c|}{ Women } & \multirow{2}{*}{$\begin{array}{c}\text { Relative } \\
\text { difference }\end{array}$} \\
\hline & $\bar{n}$ & $\%$ & $\bar{n}$ & $\%$ & & & $\bar{n}$ & $\%$ & $\bar{n}$ & $\%$ & \\
\hline $\begin{array}{l}\text { I have always liked } \\
\text { it }\end{array}$ & 94 & $89,5 \%$ & 20 & $87,0 \%$ & $2,6 \%$ & $\bar{\sigma} \downarrow q \downarrow \downarrow$ & 95 & $83,3 \%$ & 23 & $69,7 \%$ & $\begin{array}{l}13,6 \% \\
\text { more }{ }^{\lambda}\end{array}$ \\
\hline $\begin{array}{l}\text { They pay good } \\
\text { salaries once } \\
\text { graduated }\end{array}$ & 35 & $33,3 \%$ & 7 & $30,4 \%$ & $2,9 \%$ & $\bar{O} \downarrow \quad q \downarrow \downarrow$ & 25 & $21,9 \%$ & 4 & $12,1 \%$ & $\begin{array}{l}\mathbf{9 , 8 \%} \\
\text { more } \hat{~}{ }^{-1}\end{array}$ \\
\hline $\begin{array}{l}\text { There are many job } \\
\text { opportunities }\end{array}$ & 58 & $55,2 \%$ & 19 & $82,6 \%$ & $\begin{array}{l}\mathbf{- 2 7 , 4 \% ,} \\
\text { more } ᄋ\end{array}$ & $\bar{o} \downarrow q \downarrow \downarrow \downarrow$ & 43 & $37,7 \%$ & 13 & $39,4 \%$ & $-1.7 \%$ \\
\hline $\begin{array}{l}\text { My admission } \\
\text { exam grade was not } \\
\text { high enough to } \\
\text { enter my first } \\
\text { career choice }\end{array}$ & 2 & $1,9 \%$ & 1 & $4,3 \%$ & $-2,4 \%$ & & 1 & $0,9 \%$ & 1 & $3,0 \%$ & $-2,2 \%$ \\
\hline $\begin{array}{l}\text { I knew I was good } \\
\text { with computers }\end{array}$ & 42 & $40,0 \%$ & 4 & $17,4 \%$ & $\begin{array}{c}22,6 \% \\
\text { more }{ }^{\lambda}\end{array}$ & $\begin{array}{ll}\hat{\sigma} \downarrow & q \uparrow\end{array}$ & 29 & $25,4 \%$ & 9 & $27,3 \%$ & $-1,8 \%$ \\
\hline $\begin{array}{l}\text { Due to family } \\
\text { and/or teachers' } \\
\text { influences }\end{array}$ & 7 & $6,7 \%$ & 5 & $21,7 \%$ & $\begin{array}{l}-\mathbf{- 1 5 , 1 \%} \\
\text { more } \bigcirc\end{array}$ & $q \downarrow$ & 5 & $4,4 \%$ & 3 & $9,1 \%$ & $-4,7 \%$ \\
\hline Other & 3 & $2,9 \%$ & 1 & $4,3 \%$ & $-1,5 \%$ & $\overline{\partial \uparrow} \uparrow$ & 10 & $8,8 \%$ & 3 & $9,1 \%$ & $-0,3 \%$ \\
\hline
\end{tabular}


The results around the three aspects mentioned above are discussed.

(1) Gender differences amongst first year undergraduate students: Men and women appear to differ in their motivations in the following aspects: "There are many job opportunities" is more popular for women; "I knew I was good with computers" is preferred by men, and "Due to family and/or teachers' influences", is chosen more by women than men. These results are consistent with results of other investigations (in CI and other related areas) in which it has been determined that men are more self-confident and consider themselves "good" for the chosen study field, whereas women do not. In contrast, selecting a career in a field offering more job opportunities, and taking into account external opinions of parents and teachers, could reflect women's lower selfesteem and self-confidence (i.e. Rynes, Perrault, Hay and Haller, 2003 [1]; Cohoon, 2007 [3]; Lewis, McKay and Lang, 2006 [5]; Mandigan, Goodfellow and Stone, 2007 [6]).

(2) Gender differences amongst graduate students: It is interesting to see how female and male populations in the graduate program become more homogenous, that is, differences are less drastic. Joshi and Schmidt (2006) [4] find a similar homogenization of opinions after the students have received computing courses. Male graduate students continue to believe that "I have always liked it", while for female graduate students, this answer appears to be less relevant. The population that has graduated, is already working, and knows the real industry salaries, appears to have become disappointed in "They pay good salaries upon graduation" motive. This motivating factor is more important for men than for women at this level.

(3) Differences of motivation amongst members of one sex, but between two different populations: In previous discussions, we compare the relative importance between the sexes for two different populations. It can be seen in the first two rows of Table 1, that for these two motivation factors, men and women are homogeneous in the undergraduate population, whereas differences by sex emerge in the graduate student population. It is interesting to see that an opposite effect occurs with the motivators "There are many job opportunities", "I knew I was good with computers", and "Due to family and/or teachers" influences". Differences present in the undergraduate student population due to sex tend to disappear, and the graduate student populations become more homogeneous regarding these motivators. Graduate female students consider themselves in equal terms with men regarding being good with computers. They have forgotten that a major motivation for choosing to study CI was the opinions of their relatives and/or teachers. On the other hand, both men and women suffer some disappointment with "There are many job opportunities", but it is stronger on men than on women.

\subsection{2 "Some of the skills and abilities needed to study CI are...."}

The results to the question in which they were asked to point out which skills and abilities they considered necessary to study computing are presented in Table 2 . Before examining the results presented in this table, it should be noted that undergraduate first year students really do not know which skills and abilities they will need. They may 
speculate and their answers reflect the perceptions that they have or what they have "heard in the streets" or during vocational counseling sessions. On the other hand, graduate students do have a clearer picture of the skills and abilities necessary to study $\mathrm{CI}$ due to their experiences during their undergraduate studies. It is interesting to discuss differences in the answers provided by the two populations as well as gender differences amongst both populations.

Table 2. Skills and abilities perceived as necessary to study computing by first year undergraduate students and active graduate students, by sex.

\begin{tabular}{|c|c|c|c|c|c|c|c|c|c|c|c|}
\hline \multirow{3}{*}{\begin{tabular}{|l|} 
Skills and abilities \\
perceived as \\
necessary to study CI
\end{tabular}} & \multicolumn{5}{|c|}{ First year undergraduates } & \multirow{3}{*}{$\begin{array}{l}\text { Changes in } \\
\text { perception }\end{array}$} & \multicolumn{5}{|c|}{ Active graduate students } \\
\hline & \multicolumn{2}{|c|}{ Men } & \multicolumn{2}{|c|}{ Women } & \multirow{2}{*}{$\begin{array}{c}\text { Relative } \\
\text { difference }\end{array}$} & & \multicolumn{2}{|c|}{ Men } & \multicolumn{2}{|c|}{ Women } & \multirow{2}{*}{$\begin{array}{l}\text { Relative } \\
\text { difference }\end{array}$} \\
\hline & $\mathbf{n}$ & $\%$ & $\mathbf{n}$ & $\%$ & & & $\mathbf{n}$ & $\%$ & $\mathbf{n}$ & $\%$ & \\
\hline Abstraction abilities & 33 & $31,1 \%$ & 8 & $33,3 \%$ & $-2,2 \%$ & $\overline{\partial \uparrow \uparrow \quad q \uparrow \uparrow}$ & 97 & $85,1 \%$ & 27 & $81,8 \%$ & $3,3 \%$ \\
\hline Graphical capabilities & 38 & $35,8 \%$ & 8 & $33,3 \%$ & $2,5 \%$ & $\hat{O} \downarrow \downarrow$ O $\downarrow \downarrow$ & 6 & $5,3 \%$ & 3 & $9,1 \%$ & $-3,8 \%$ \\
\hline $\begin{array}{l}\text { Ability to stay for } \\
\text { hours in front of a } \\
\text { computer }\end{array}$ & $\overline{54}$ & $50,9 \%$ & 14 & $58,3 \%$ & $\begin{array}{l}-7,4 \% \\
\text { more } q\end{array}$ & $\overline{o \downarrow}+\phi \downarrow \downarrow$ & 48 & $42,1 \%$ & 14 & $42,4 \%$ & $-0,3 \%$ \\
\hline $\begin{array}{l}\text { Ability to } \\
\text { communicate with } \\
\text { people }\end{array}$ & 21 & $19,8 \%$ & 7 & $29,2 \%$ & $\begin{array}{l}-\mathbf{- 9 , 4 \%} \% \\
\text { more } q\end{array}$ & $\overline{\delta \uparrow} \quad+\uparrow \uparrow$ & 38 & $33,3 \%$ & 16 & $48,5 \%$ & $\begin{array}{l}-15,2 \% \\
\text { more } q\end{array}$ \\
\hline Creativity & 64 & $60,4 \%$ & 19 & $79,2 \%$ & $\begin{array}{l}\mathbf{- 1 8 , 8 \%} \\
\text { more } \circ\end{array}$ & 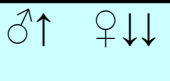 & 81 & $71,1 \%$ & 22 & $66,7 \%$ & $4,4 \%$ \\
\hline $\begin{array}{l}\text { Mathematical } \\
\text { knowledge and ability }\end{array}$ & 81 & $76,4 \%$ & 19 & $79,2 \%$ & $-2,8 \%$ & 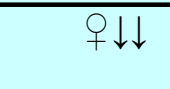 & 82 & $71,9 \%$ & 21 & $63,6 \%$ & $\begin{array}{c}\mathbf{8 , 3 \%} \\
\text { more }{ }^{\lambda}\end{array}$ \\
\hline Leadership & 20 & $18,9 \%$ & 7 & $29,2 \%$ & $\begin{array}{l}\mathbf{- 1 0 , 3 \%} \\
\text { more } \circ\end{array}$ & & 21 & $18,4 \%$ & 10 & $30,3 \%$ & $\begin{array}{l}-\mathbf{- 1 1 , 9 \%} \\
\text { more } ᄋ\end{array}$ \\
\hline Responsibility & 61 & $57,5 \%$ & 17 & $\overline{70,8 \%}$ & $\begin{array}{l}-13,3 \% \\
\text { more } ㅇ\end{array}$ & $\hat{\sigma} \downarrow \quad+\downarrow$ & 59 & $51,8 \%$ & 21 & $63,6 \%$ & $\begin{array}{l}-11,9 \% \\
\text { more } 9\end{array}$ \\
\hline $\begin{array}{l}\text { Good stress } \\
\text { management }\end{array}$ & 50 & $47,2 \%$ & 10 & $41,7 \%$ & $5,5 \%$ & $\overline{\partial \uparrow} \quad \phi \uparrow \uparrow$ & 63 & $55,3 \%$ & 25 & $75,8 \%$ & $\begin{array}{l}-\mathbf{2 0 , 5 \%} \\
\text { more } q\end{array}$ \\
\hline $\begin{array}{l}\text { Ability to keep up to } \\
\text { date in the field }\end{array}$ & 78 & $73,6 \%$ & 17 & $70,8 \%$ & $2,8 \%$ & $\overline{0 \uparrow}$ & 86 & $75,4 \%$ & 27 & $81,8 \%$ & $-6,4 \%$ \\
\hline Others & 2 & $1,9 \%$ & 0 & $0,0 \%$ & $1,9 \%$ & & 4 & $3,5 \%$ & 2 & $6,1 \%$ & $-2,6 \%$ \\
\hline
\end{tabular}

(1) Gender differences amongst first year undergraduate students: The greater differences between male and female answers (highlighted in green and yellow), are: "Creativity", "Responsibility", "Leadership", "Ability to communicate with people", "Ability to spend hours in front of a computer" (listed from highest to lowest relative difference). Note that in all of them, women selected these skills and abilities more frequently than men. In general, it appears that women just starting the undergraduate program believe that they require more skills and abilities to succeed in the study plan than men. This may be an important factor in explaining why fewer women aspire to study CI. They see a greater challenge in front of them. Studying CI seems to be seen as more complex for women than for men. It would be interesting to see if there are studies that show similar results.

(2) Gender differences amongst graduate students: For graduate women, as for their younger counterparts, skills and abilities such as "Ability to communicate with people", "Responsibility", and "Leadership" are relatively more significant 
than for men. It needs to be pointed out here the significant change in the importance of "Good stress management". For graduate women, this has become much more important than for men. Another interesting aspect is to see how the relevance of "Mathematical knowledge and abilities" loses some significance for the female graduate students population. Disseminating this information is important because some studies have shown that women avoid studying CI due to their fear of Mathematics, as described by Chavarria (1990) [2].

(3) Differences in perceptions amongst members of one sex, but between two different populations: Since the column Changes in Perception involves so many changes, we try to facilitate its interpretation visualizing these changes using Figure 1 for men and Figure 2 for women. In these figures, its distance from the graph center determines the relative importance of one issue. For example, the closer a skill or ability is graphed from the center, the less important it is for students. The graphs in both figures reflect changes when comparing the behavior of the two populations (undergraduate and postgraduate) of the same sex.

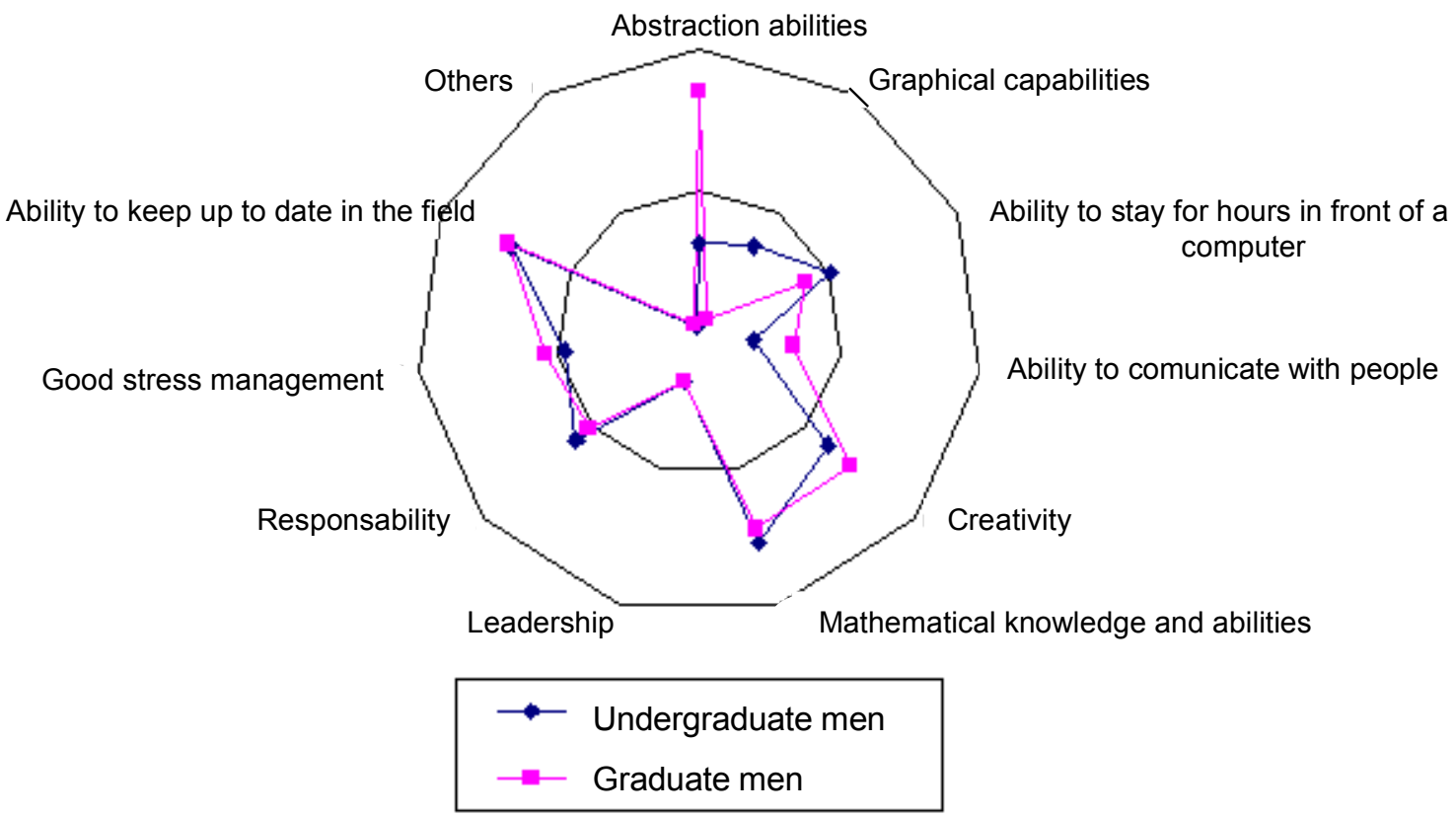

Figure 1. Changes in relative importance of skills and abilities required for studying CI according to undergraduate and graduate male students. In this graph the distance from the center, reflects the importance of the respective ability or aptitude, i.e. closer means being less important.

Figure 1 shows that after having finished a study plan in CI, men give greater importance to the "Abstraction abilities" and a little more relevance to "Creativity" and "Ability to communicate with people". In addition, their perception of the importance in "Ability to stay hours in front of a computer" and "Graphical capabilities" decreases. 


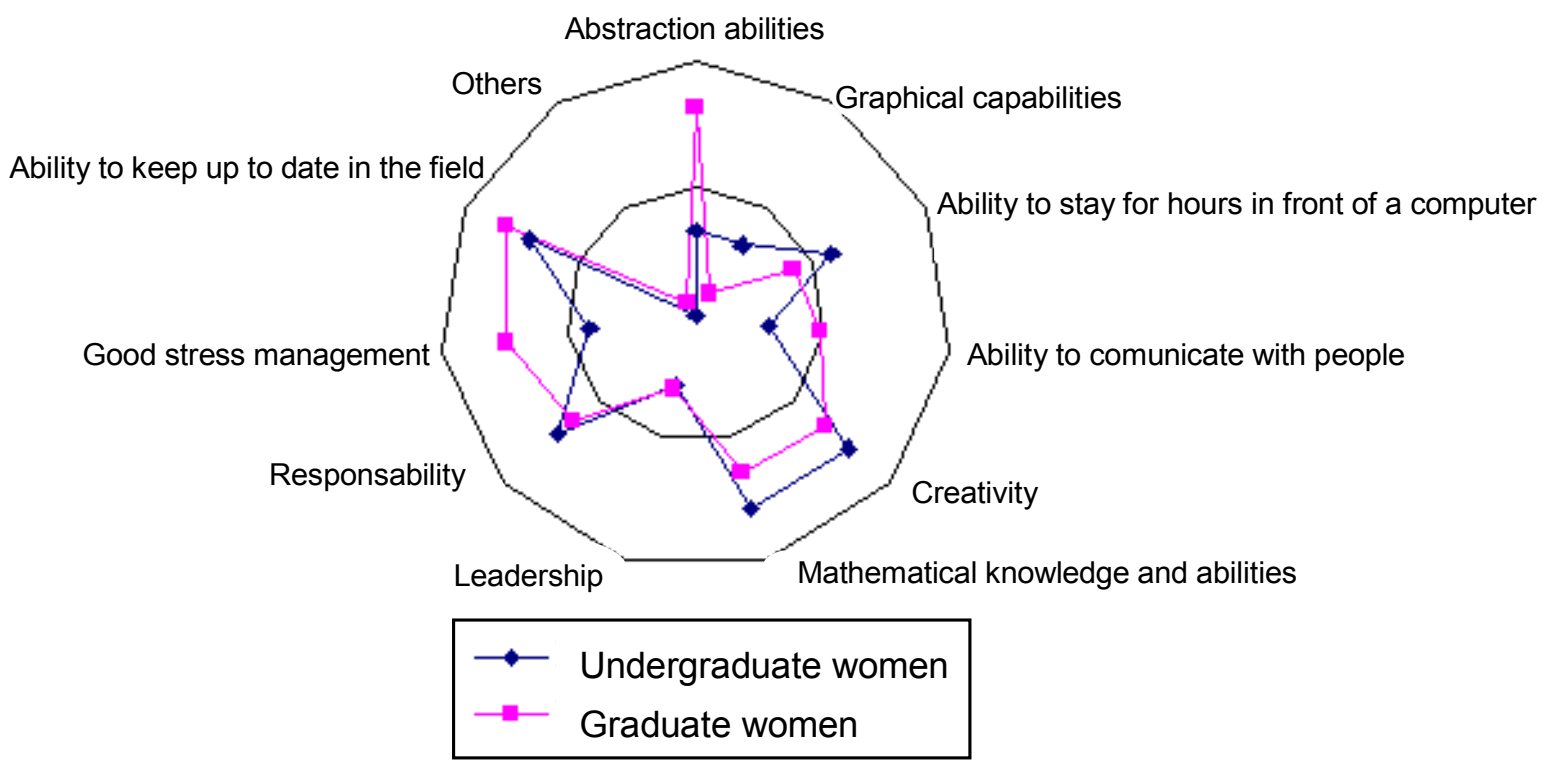

Figure 2. Changes in relative importance of skills and abilities required for studying CI, according to undergraduate and graduate female students. In this graph the distance from the center reflects the importance of the respective ability or aptitude, i.e. closer means being less important.

As shown in Figure 2, after having finished the study plan in computing, women also give greater importance to the "Abstraction abilities". In their perception, "Ability to stay for hours in front of a computer", "Graphical capabilities", "Creativity", and the need for "Mathematical knowledge and abilities" fall. Note that for graduate women "Good stress management" and "Capacity to communicate with people" becomes very important. This is interesting because it is not part of the expected profile of a CI professional.

\subsection{3 "Some things I dislike like about studying CI are..."}

The answers to the question "Some things I dislike like about studying CI are... (more than one option can be selected)" are presented in Table 3 to complete the study, and to try to understand gender differences that may be inhibiting the enrollment of women into CI careers. As previously stated, the results presented in this table should be analyzed taking into account that first year undergraduate students do not know the study plan, and therefore their opinions reflect perceptions that they have heard or read about, and have learned from vocational counseling sessions. On the other hand, graduate students do know what studying CI is, both academically and professionally. We discuss the differences between the two populations - undergraduate and graduate students--, and the differences by sex, within each population.

(1) Gender differences amongst first year undergraduate students: Table 3 reflects gender differences in undergraduate student dislikes. "A big effort is required to stay up to date ", and "It requires to be very good at Math" are more important concerns amongst women, whereas men seem to be more worried about "It inhibits me to be in direct contact with other people" than women. 
(2) Gender differences amongst graduate students: As for undergraduate women, "A big effort is required to stay up to date" is a major concern mostly for female graduate students. This result was to be expected since women usually have less time available to continue studying upon graduation, due to having more family responsibilities. The difference in perception between graduate men and women over "Other people may feel that I am weird and/or asocial" is very interesting as well. Graduate students are more mature, and graduate women may possibly have had more discriminating experiences, both by members of the opposite sex and of the same sex, as the result of being considered weird for being in a study field that is viewed as very difficult, dry, and that requires Math. Which of us has never disguised the truth, hiding our profession, just not to "scare way" someone we have just met? This phenomenon is not the same for men. Which men have never boasted of being successful just by studying CI? On the other hand, graduate men, similar to undergraduate men, seem to have greater concern over "It inhibits me to be in direct contact with other people" than women. We believe that this phenomenon should be investigated further to understand its causes. Finally, the concern "It requires to be very good at Math" is no longer important for both men and women, once they have completed their study plan.

Table 3. Things that first year undergraduate students and active graduate students dislike about studying computing, by sex.

\begin{tabular}{|c|c|c|c|c|c|c|c|c|c|c|c|}
\hline \multirow{3}{*}{$\begin{array}{l}\text { Things I dislike } \\
\text { about studying } \\
\text { computers }\end{array}$} & \multicolumn{5}{|c|}{ First year undergraduates } & \multirow{3}{*}{$\begin{array}{l}\text { Changes in } \\
\text { perception }\end{array}$} & \multicolumn{5}{|c|}{ Active graduate students } \\
\hline & \multicolumn{2}{|c|}{ Men } & \multicolumn{2}{|c|}{ Women } & \multirow{2}{*}{$\begin{array}{c}\text { Relative } \\
\text { difference }\end{array}$} & & \multicolumn{2}{|c|}{ Men } & \multicolumn{2}{|c|}{ Women } & \multirow{2}{*}{$\begin{array}{l}\text { Relative } \\
\text { difference }\end{array}$} \\
\hline & $\mathbf{n}$ & $\%$ & $\bar{n}$ & $\%$ & & & $\bar{n}$ & $\%$ & $\bar{n}$ & $\%$ & \\
\hline $\begin{array}{l}\text { It is a very difficult } \\
\text { field }\end{array}$ & 4 & $3,8 \%$ & 1 & $4,2 \%$ & $-0,4 \%$ & & 1 & $0,9 \%$ & 0 & $0,0 \%$ & $0,9 \%$ \\
\hline $\begin{array}{l}\text { Working with } \\
\text { computers requires } \\
\text { staying in front of the } \\
\text { computer for many } \\
\text { hours }\end{array}$ & 26 & $24,5 \%$ & 7 & $29,2 \%$ & $-4,6 \%$ & $\overline{\partial \uparrow}$ & 41 & $36,0 \%$ & 10 & $30,3 \%$ & $5,7 \%$ \\
\hline $\begin{array}{l}\text { A big effort is } \\
\text { required to stay up to } \\
\text { date }\end{array}$ & 9 & $8,5 \%$ & 6 & $25,0 \%$ & $\begin{array}{l}-16,5 \% \\
\text { more } \varnothing\end{array}$ & $\overline{\partial \uparrow} \uparrow \quad+\uparrow$ & 28 & $24,6 \%$ & 13 & $39,4 \%$ & $\begin{array}{l}-14,8 \% \\
\text { more } \varnothing\end{array}$ \\
\hline $\begin{array}{l}\text { Other people may } \\
\text { feel that I am weird } \\
\text { and/or asocial }\end{array}$ & 7 & $6,6 \%$ & 1 & $4,2 \%$ & $2,4 \%$ & $\overline{o \uparrow} \uparrow \uparrow \uparrow$ & 12 & $10,5 \%$ & 6 & $18,2 \%$ & $\begin{array}{l}-7,7 \% \\
\text { more } q\end{array}$ \\
\hline $\begin{array}{l}\text { It is a very technical } \\
\text { field }\end{array}$ & 4 & $3,8 \%$ & 2 & $8,3 \%$ & $-4,6 \%$ & & 6 & $5,3 \%$ & 2 & $6,1 \%$ & $-0,8 \%$ \\
\hline $\begin{array}{l}\text { It requires to be very } \\
\text { good at Math }\end{array}$ & 15 & $14,2 \%$ & 6 & $25,0 \%$ & $\begin{array}{l}-\mathbf{- 1 0 , 8 \%} \\
\text { more } q\end{array}$ & $\overline{O \downarrow} \quad q \downarrow \downarrow$ & 9 & $7,9 \%$ & 2 & $6,1 \%$ & $1,8 \%$ \\
\hline $\begin{array}{l}\text { It inhibits me to be in } \\
\text { direct contact with } \\
\text { other people }\end{array}$ & 18 & $17,0 \%$ & 2 & $8,3 \%$ & $\begin{array}{l}\mathbf{8 , 6 \%} \\
\text { more }{ }^{\widehat{A}}\end{array}$ & & 20 & $17,5 \%$ & 3 & $9,1 \%$ & $\begin{array}{l}\mathbf{8 , 4 \%} \\
\text { more }{ }^{\lambda}\end{array}$ \\
\hline Others & 2 & $1,9 \%$ & 1 & $4,2 \%$ & $-2,3 \%$ & & 10 & $8,8 \%$ & 4 & $12,1 \%$ & $-3,3 \%$ \\
\hline
\end{tabular}


(3) Differences of motivation amongst members of one sex, but between two different populations: Notice that for male and female graduate students issues that impact their daily lives such as: "A big effort is required to stay up to date", "Other people may feel that I am weird and/or asocial ", and "Working with computers requires staying in front of the computer for many hours" become of greater relevance. Finally, it is interesting to highlight that once they have completed their study plan, issues such as "It is a very difficult field", "It is a very technical field", and "It requires to be very good at Math" are no longer major concerns for neither men nor women.

\section{Conclusions}

The results of the first three questions of the survey show that:

- There are gender differences in the perception of undergraduate and graduate male and female students on the motivations for starting CI studies. First year undergraduate women give more importance to external views, from teachers, parents, etc, than first year undergraduate men. First year undergraduate men reflect more self-esteem than women on their ability to be successful in the field. For graduate students the answers to motivating factors are more homogeneous. However, more graduate men than women reported that they had always liked computers, and even though for both sexes getting a good salary becomes less important, for graduate men it is still more important than for women. We also found that there is a change in responses for both sexes as a result of the knowledge that graduate students have on the field. For example, we found that graduate women consider themselves on equal terms with men regarding "having being good at computers". This self-perception is absent from the first year undergraduate women. Similarly, graduate women have forgotten that a major source of motivation for the career choice was the views of their relatives and /or teachers.

- There are gender differences in perceptions about the skills and abilities needed to study CI amongst undergraduate and graduate students. Women, in general, give greater importance to skills and abilities needed for the field than men. We also found significant differences when comparing the two populations (undergraduate and graduate students) of the same sex. Women and men change their perception about the skills and abilities needed to study CI in a different way, as a result of experience in the academic and labor worlds. Graduate women, who have already finished their undergraduate program and are working in the professional field, give much more relevance to the skills and abilities that enable them to interact socially. Finally, male and female graduate students give greater importance than undergraduates to abstraction capabilities as a skill necessary to succeed in computing.

- Regarding what they do not like about studying CI, we found differences by gender at both undergraduate and graduate levels. For example, women in both programs have a greater dislike for the obligation to keep up learning and 
updating their knowledge than men. However, it is interesting to note that for both male and female graduate students, being good at math is no longer so important. It seems that for male and female graduate students the everyday concerns assume greater importance than for undergraduate populations, and concerns associated with difficulties to succeed in the study plan (as "Computer Science is a difficult field") are no longer as relevant.

We believe it is very important to have confirmed that differences, due to gender, exist on motivational and inhibiting factors to start studying CI. Although we are completely sure that we will not be able to find a single factor that can explain the low participation of women in the Computer Science field, we know that various factors, and the relationship between them, can begin to help us understand this phenomenon. We believe it is fundamental to try to reverse this trend, because, as we said in Marin (2007) [7], the low participation of women in the field may have many implications such as: leaving women out of labor fields with growing demand, professional prestige, and good salaries; inhibiting the industry from a source of skilled labor; and impoverishing the Computer Sciences and Informatics field by losing the different perspectives that women could provide.

\section{References}

[1] Beyer, S., Rynes, K., Perrault, J., Hay, K., and Haller, S. Gender differences in computer science students. In Proceedings of the 34th SIGCSE Technical Symposium on Computer Science Education (Reno, Navada, USA, February 19 23, 2003). SIGCSE '03. ACM Press, New York, NY, 49-53.

[2] Chavarría, S. Women's choice of careers at the University. In Proceedings of the European and Third World GASAT Conference. Jonkoping, Sweden. (1990).

[3] Cohoon, J. M. Gendered experiences of computing graduate programs. In Proceedings of the 38th SIGCSE Technical Symposium on Computer Science Education (March , 2007). ACM Press, New York, NY, 546-550.

[4] Joshi, K. D. and Schmidt, N. L. Is the information systems profession gendered?: characterization of IS professionals and IS career. SIGMIS Database 37, 4 (Nov. 2006), 26-41.

[5] Lewis, S., McKay, J., and Lang, C. The next wave of gender projects in IT curriculum teaching at universities. In Proceedings of the 8th Austalian Conference on Computing Education - Volume 52. Hobart, Australia (January 16 - 19, 2006). D. Tolhurst and S. Mann, Eds. ACM International Conference Proceeding Series, vol. 165. Australian Computer Society, Darlinghurst, Australia, 135-142.

[6] Mandigan, E.M., Goodfellow, M. and Stone, J.A. Gender, Perceptions, and Reality: Technological Literacy Among First-Year Students. In Proceedings of the 38th SIGCSE Technical Symposium on Computer Science Education. Covington, Kentucky, USA (March, 2007). SIGCSE '07. ACM Press, New York, NY, 410-414.

[7] Marín, G., Barrantes, E.G., and Chavarría, S. ¿Se estarán extinguiendo las mujeres de la carrera de Computación e Informática? In Conferencia Latinoamericana de Informática, CLEI 2007, San José, Costa Rica, 2007. 